\title{
MENERAPKAN NILAI ISLAM DALAM PENGEMBANGAN MUTU PENDIDIKAN TERKAIT MANAJEMEN SUMBER DAYA MANUSIA
}

\author{
Handika dan Yogie Dwi Saputra \\ Fakultas Ekonomi, Jurusan Manajemen, Universitas Bangka Belitung, Indonesia \\ Jln. Kampus terpadu ubb, kel. Balunijuk, kec. Merawang, balunijuk, merawang, kabupaten bangka, kepulauan \\ bangka belitung 33172 \\ e-mail : dikabangok02@gmail.com
}

\begin{abstract}
ABSTRAK
Manajemen sumber daya manusia adalah suatu bidang manajemen khusus yang mempelajari hubungan dan peranan manusia dalam suatu organisasi. Manusia adalah tenaga kerja yang bekerja dalam suatu perusahaan. Salah satu faktor suatu pendidikan bisa berkembang adalah adanya manajemen sumber daya manusia yang baik dan sesuai dengan nilai-nilai Islam. Dengan adanya sumber daya manusia yang berkualitas akan dapat berpengaruh pada proses dan kemajuan yang lebih baik dalam bidang pendidikan tersebut. Meningkatkan sumber daya manusia menjadi semakin penting untuk institusi yang digunakan untuk mendapatkan kontrol yang lebih baik melalui lembaga mereka sendiri. Lembaga harus menunjukkan bahwa mereka mampu memberikan pendidikan yang berkualitas untuk pelajar. Untuk setiap institusi, kualitas adalah agenda dan kualitas utama perbaikan adalah tugas yang paling penting. Salah satu yang harus di perhatikan dalam Manajemen sumber daya manusia di Indonesia ini adalah peningkatan kualitas mutu pendidikan dengan tujuan untuk mengubah institusi yang mengoperasikannya menjadi tim yang tulus, tanpa konflik dan persaingan internal, untuk mencapai satu tujuan, yaitu untuk kemajuan pendidikan yang lebih baik.

Hasil penelitian ini menunjukkan bahwa: Perencanaan sumber daya untuk meningkatkan mutu pendidikan seleksi dan orientasi, serta penempatan sumber daya manusia secara profesional. Pelaksanaan sumber daya dilakukan dengan kegiatan pendidikan, pelatihan dan pengembangan sumber daa manusia yang berperan dalam peningkatan mutu pendidikan yang berkualitas sesuai nilai-nilai islam.
\end{abstract}

Kata kunci: Manajemen, Sumber Daya Manusia, Peningkatan dan Kualitas mutu pendidikan

\begin{abstract}
Human resource management is a specialized management field that studies the relationships and roles of humans in an organization. Humans are workers who work in a company. One of the factors that can develop education is the existence of good and appropriate human resource management in accordance with Islamic values. With the existence of quality human resources will be able to influence the process and better progress in the field of education. Increasing human resources is becoming increasingly important for institutions that are used to gain better control through their own institutions. Institutions must show that they are able to provide quality education for students. For each institution, quality is the agenda and the main quality of improvement is the most important task. One of the things that must be considered in human resource management in Indonesia is to improve the quality of education with the aim of changing the institutions that operate it into a sincere team, without conflict and internal competition, to achieve a goal, namely for the betterment of education.

The results of this study indicate that: Planning resources to improve the quality of education selection and orientation, as well as the placement of human resources in a professional manner. The implementation of resources is carried out through educational activities, training and development of human resources that play a role in improving the quality of quality education in accordance with Islamic values.
\end{abstract}

Keywords: Management, Human Resources, Improvement and Quality of education quality 


\section{A .Pendahahuluan}

Pembinaan pendidikan yang dilakukan oleh Kementerian Agama selama ini masih perlu langkah-langkah penyesuaian yang strategis. Dalam proses peningkatan kualitas sumber daya manusia, pendidikan memegang peran yang sangat penting dan harus merupakan suatu proses yang terintegrasi dengan proses peningkatan kualitas pembinaan lembaga-lembaga yang terkait secara keseluruhan. Salah satu peran penting pendidikan adalah menyiapkan sumber daya manusia yang berkualitas sesuai dengan perubahan zaman agar tidak terjadi kesenjangan antara realitas dan idealitas. (H. Abd. Wahid Tahir).

Menurut Sakai (2008) bahwa penerapan nilai-nilai islam dalam organisasi merupakan bagian yang penting dalam meningkatkan Sumber Daya Manusia (SDM). Riset menunjukkan bahwa tingkat kedisiplinan pribadi sangat ditekankan untuk meningkatkan profesionalisme SDM, nilai-nilai yang diambil langsung dari Al-Quran dikaitkan kedalam kegiatan operasional. Profesionalisme SDM diatur dalam Q.S. [Al-Qasas: 26] sebagai berikut :

Menjadi pribadi yang kuat dan amanah merupakan hal mutlak sebagai bentuk profesionalisme sehingga bukan hanya sekedar formalitas. Peningkatan potensi SDM melalui pengembangan organisasi sangat penting. Pengembangan SDM melalui pembelajaran organisasi yang diaplikasikan melalui program pelatihan yang telah disesuaikan. Dalam suatu organisasi peningkatan kompetensi sebagai tolak ukur keberhasilan. Mengingat, kompetensi menunjang dalam pengembangan karir SDM. Pembelajaran organisasi dapat berupa soft skill maupun hard skill. Pembelajaran organisasi harus menekankan nilai-nilai Islam yang mencerminkan prilaku organisasi. Kompetensi sebagai alat untuk meningkatkan kinerja perusahaan berdasarkan hasil kerja yang efektif dan efisien. Sehingga, perlu diperhatikan aspek kompetensi mana yang perlu ditingkatkan dalam internal perusahaan. Sebab, tidak semua level jabatan tertentu membutuhkan tingkat kompetensi yang tinggi. Kompetensi berorientasi pada kinerja superior setiap individu. Berger \& Berger (2004; dikutip Vathanophas \& Thai-Ngam, 2007) memaparkan faktor-faktor keberhasilan implementasi kompetensi dalam sebuah perusahaan ditunjukkan dengan budaya berorientasi kinerja, rendahnya pergantian karyawan, level kepuasan karyawan yang tinggi, kader-kader pengganti yang berkualitas, investasi yang efektif dalam kompensasi dan pengembangan karyawan dan penggunaan kompetensi kelembagaan dalam proses seleksi dan evaluasi kinerja. Nilai sebuah kompetensi yang dimiliki oleh SDM dapat dipupuk melalui program pelatihan, pendidikan dan pengembangan yang seluruhnya berorientasi pada tuntutan kerja nyata dengan adanya penekanan pada aspek kompetensi (Knowledge, Skill, and Ability).

Salah satu permasalahan pendidikan yang dihadapi oleh bangsa Indonesia adalah rendahnya mutu pendidikan pada setiap jenjang dan satuan pendidikan, khususnya pendidikan dasar dan menengah. Berbagai usaha telah dilakukan untuk meningkatkan mutu pendidikan nasional, misalnya pengembangan kurikulum nasional dan lokal, peningkatan kompetensi guru melalui pelatihan, pengadaan buku dan alat pelajaran, pengadaan dan perbaikan sarana dan prasarana pendidikan, dan peningkatan mutu manajemen sekolah. Namun demikian, berbagai indikator mutu pendidikan belum menunjukan peningkatan yang berarti. Sebagian sekolah, terutama di kota-kota, menunjukan peningkatan mutu pendidikan yang cukup menggembirakan, namun sebagian lainnya masih memprihatinkan.

Namun saat ini dunia pendidikan kita belum sepenuhnya dapat memenuhi harapan masyarakat. Fenomena itu ditandai dari rendahnya mutu lulusan, penyelesaian masalah pendidikan yang tidak sampai tuntas, atau cenderung tambal sulam, bahkan lebih berorintasi proyek. Akibatnya, seringkali hasil pendidikan mengecewakan masyarakat. Mereka terus mempertanyakan relevansi pendidikan dengan kebutuhan masyarakat dalam dinamika kehidupan ekonomi, politik , sosial, dan budaya. Kualitas lulusan pendidikan kurang sesuai dengan kebutuhan pasar tenaga kerja dan pembangunan, baik industri, perbankan, telekomunikasi, maupun pasar tenaga kerja sektor lainnya yang cenderung menggugat eksistensi sekolah. Bahkan SDM yang disiapkan melalui pendidikan sebagai generasi penerus belum sepenuhnya memuaskan bila dilihat dari segi akhlak, moral, dan jati diri bangsa dalam kemajemukan budaya bangsa.

Berbicara mengenai kualitas sumberdaya manusia. Islam memandang bahwa pembinaan sumberdaya manusia tidak dapat dilepaskan dari pemikiran mengenai manusia itu sendiri, dengan demikian Islam memiliki konsep yang sangat jelas, utuh dan komprehensif mengenai pembinaan sumberdaya manusia. Konsep ini tetap aktual dan relevan untuk diaplikasikan sepanjang zaman.

Untuk menciptakan sebuah lembaga pendidikan yang bermutu sebagaimana yang diharapkan banyak orang atau masyarakat bukan hanya menjadi tanggungjawab sekolah, tetapi merupakan tanggungjawab dari semua pihak termasuk didalamnya orang tua dan dunia usaha sebagai customer internal dan eksternal dari sebuah lembaga pendidikan. Arcaro S Jerome menyampaikan bahwa terdapat lima karakteristik sekolah yang bermutu yaitu: 1) Fokus pada pelanggan. 2) Keterlibatan total 3) Pengukuran 4) Komitmen 5) Perbaikan berkelanjutan. Mutu produk pendidikan akan dipengaruhi oleh sejauh 
mana lembaga mampu mengelola seluruh potensi secara optimal mulai dari tenaga kependidikan, peserta didik, proses pembelajaran, sarana pendidikan, keuangan dan termasuk hubungannya dengan masyarakat. Pada kesempatan ini, lembaga pendidikan Islam harus mampu merubah paradigma baru pendidikan yang berorientasi pada mutu semua aktifitas yang berinteraksi didalamnya, seluruhnya mengarah pencapaian pada mutu.

Dalam upaya peningkatan SDM, peranan pendidikan sangat signifikan. Oleh karena itu sangat penting bagi pembangunan nasional untuk memfokuskan peningkatan mutu pendidikan. Pendidikan yang bermutu akan diperoleh pada sekolah yang bermutu, dan sekolah yang bermutu akan menghasilkan SDM yang bermutu pula.

Berkaitan dengan peningkatan mutu bahwa $85 \%$ dari masalah-masalah mutu terletak pada manajemen (pengelolaan), oleh sebab itu sejak dini manajemen haruslah dilaksanakan seefektif dan seefisien mungkin. Salah satu bentuk manajemen yang berhasil dimanfaatkan dalam dunia industri dan bisa diadaptasi dalam dunia pendidikan adalah TQM (Total Quality Management) pada sistem pendidikan yang sering disebut sebagai: Total Quality Management in Education (TQME).

Manajemen adalah suatu proses atau kerangka kerja, yang melibatkan bimbingan atau pengarahan suatu kelompok orang kearah tujuan-tujuan organisasional atau maksud-maksud yang nyata. Manajemen adalah suatu kegiatan, pelaksanaannya adalah "managing" -pengelolaan-, sedangkan pelaksananya disebut dengan manager atau pengelola.[6]

Manajemen juga merupakan ilmu pengetahuan atau seni. Dikatakan sebagai seni adalah suatu pengetahuan bagaimana mencapai hasil yang diinginkan atau dengan kata lain seni merupakan kecakapan yang diperoleh dari pengalaman-pengalaman dan pelajaran serta kemampuan untuk menggunakan pengetahuan manajemen.

Pada awalnya istilah manajemen cenderung ditempatkan pada dunia bisnis dan perusahaan. Mengingat pentingnya peranan manajemen dalam usaha pengelolaan dunia pendidikan maka istilah manajemen diadaptasikan dalam dunia pendidikan. Dengan kata lain pendidikan memposisikan istilah menajemen dalam dunia pendidikan dan memunculkan istilah yang disebut dengan manajemen pendidikan.

Adapun pengertian manajemen pendidikan Islam adalah suatu proses penataan/pengelolaan lembaga pendidikan Islam yang melibatkan sumber daya manusia muslim dan non muslim dalam menggerakkannya untuk mencapai tujuan pendidikan Islam secara efektif dan efisien.

Berbeda berbeda redaksi dengan Ramayulis, menurutnya manajemen pendidikan
Islam adalah proses pemanfaatan semua sumber daya yang dimiliki (ummat Islam, lembaga pendidikan atau lainnya) baik perangkat keras maupun lunak. Pemanfaatan tersebut dilakukan melalui kerjasama dengan orang lain secara efektif, efisien, dan produktif untuk mencapai kebahagiaan dan kesejahteraan baik di dunia maupun di akhirat.[9]

Ramayulis menyatakan bahwa pengertian yang sama dengan hakikat manajemen adalah al-tadbir (pengaturan). Kata ini merupakan derivasi dari kata dabbara (mengatur) yang banyak terdapat dalam $\mathrm{Al}$ Qur'an seperti firman Allah SWT :

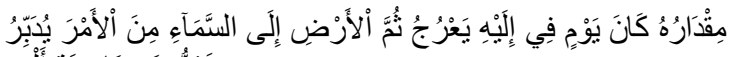

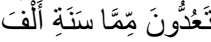

Artinya: Dia mengatur urusan dari langit ke bumi, kemudian (urusan) itu naik kepadanya dalam satu hari yang kadarnya adalah seribu tahun menurut perhitunganmu (Al Sajdah : 05).

Dari isi kandungan ayat di atas dapatlah diketahui bahwa Allah swt adalah pengatur alam (manager). Keteraturan alam raya ini merupakan bukti kebesaran Allah swt dalam mengelola alam ini. Namun, karena manusia yang diciptakan Allah SWT telah dijadikan sebagai khalifah di bumi, maka dia harus mengatur dan mengelola bumi dengan sebaik-baiknya sebagaimana Allah mengatur alam raya ini.

Dalam pandangan ajaran Islam, segala sesuatu harus dilakukan secara rapi, benar, tertib, dan teratur. Proses-prosesnya harus diikuti dengan baik dan boleh dilakukan secara asal-asalan.[12] Mulai dari urusan terkecil seperti mengatur urusan Rumah Tangga sampai dengan urusan terbesar seperti mengatur urusan sebuah negara semua itu diperlukan pengaturan yang baik, tepat dan terarah dalam bingkai sebuah manajemen agar tujuan yang hendak dicapai bisa diraih dan bisa selesai secara efisien dan efektif.

\section{B. Metodologi}

Penelitian dilakukan dengan melakukan kajian literatur dan hasil penelitian sebelumnya mengenai penerapan nilai islam dalam pengembangan mutu pendidikan terkait manajemen sumber daya manusia. Penelitian ini berdasarkan data sekunder yang dikumpulkan dari buku, jurnal, dan internet. Penelitian ini mengaplikasikan kerangka kerja konseptual yang dikembangkan untuk menggambarkan masing-masing kebijakan praktisnya secara mendalam.

\section{Hasil dan pembahasan}

\section{Manajemen Peningkatan Mutu}

Berbicara mengenai kualitas sumber daya manusia, pendidikan memegang peran yang sangat penting dalam proses peningkatan kualitas sumber 
daya manusia. Untuk itu perlu peran serta seluruh masyarakat dan pemerintah untuk mewujudkan hal tersebut. Hal tersebut dapat dilakukan dengan meningkatkan sumber daya manusia

Pengertian mengenai mutu pendidikan mengandung makna yang berlainan. Namun, perlu ada suatu pengertian yang operasional sebagi suatu pedoman dalam pengelolaan pendidikan untuk sampai pada pengertian mutu pendidikan, kita lihat terlebih dahulu pengertian mutu pendidikan.

Korelasi mutu dengan pendidikan, sebagaimana pengertian yang dikemukakan oleh Dzaujak Ahmad, .Mutu pendidikan adalah kemampuan sekolah dalam pengelolaan secara operasional an efisien tehadap komponen-komponen yang berkaitan dengan sekolah sehingga menghasilkan nilai tambah terhadap komponen tersebut menurut norma/ standar yang berlaku.

Dari penjelasan diatas dapat disimpulkan bahwa bicara pendidikan bukanlah upaya sederhana, melainkan suatu kegiatan dinamis dan penuh tantangan. Pendidikan selalu berubah seiring dengan perubahan jaman. Oleh karena itu pendidikan senantiasa memerlukan upaya perbaikan dan peningkatan mutu sejalan dengan semakin tingginya kebutuhan dan tuntunan kehidupan masyarakat.

Manajemen peningkatan mutu pendidikan di sekolah adalah suatu metode peningkatan mutu yang bertumpu pada pendidikan di sekolah itu sendiri, mengaplikasikan sekumpulan teknik, mendasarkan pada ketersediaan data kuantitatif \& kualitatif, dan pemberdayaan semua komponen sekolah untuk secara berkesinambungan meningkatkan kapasitas dan kemampuan organisasi sekolah guna memenuhi kebutuhan peserta didik dan masyarakat. Dalam Peningkatan Mutu yang selanjutnya disingkat MPM, terkandung upaya a) mengendalikan proses yang berlangsung di sekolah baik kurikuler maupun administrasi, b) melibatkan proses diagnose dan proses tindakan untuk menindak lanjuti diagnose, c) memerlukan partisipasi semua fihak: Kepala sekolah, guru, staf administrasi, siswa, orang tua dan pakar.

Berdasarkan pengertian di atas dapat dipahami bahwa Manajemen Peningkatan Mutu memiliki prinsip :

- Peningkatan mutu harus dilaksanakan di lembaga-lembaga pendidikan

- Peningkatan mutu hanya dapat dilaksanakan dengan adanya kepemimpinan yang baik

- Peningkatan mutu harus didasarkan pada data dan fakta baik bersifat kualitatif maupun kuantitatif

- Peningkatan mutu memiliki tujuan bahwa sekolah dapat memberikan kepuasan kepada siswa, orang tua dan

- masyarakat.

2. Manajemen Peningkatan Mutu Pendidikan Islam
Berbicara mengenai kualitas sumberdaya manusia. Islam memandang bahwa pembinaan sumberdaya manusia tidak dapat dilepaskan dari pemikiran mengenai manusia itu sendiri, dengan demikian Islam memiliki konsep yang sangat jelas, utuh dan komprehensif mengenai pembinaan sumberdaya manusia. Konsep ini tetap aktual dan relevan untuk diaplikasikan sepanjang zaman. Peningkatan mutu atau kualitas pembelajaran merupakan inti dari reformasi pendidikan di negara manapun. Hal ini disebabkan oleh asumsi bahwa, peningkatan mutu pendidikan pada madrasah yang memiliki peran penting dalam peningkatan mutu pendidikan nasional, tergantung pada kualitas pembelajaran. ( H. Abd. Wahid Tahir ).

Mutu produk pendidikan akan dipengaruhi oleh sejauh mana lembaga mampu mengelola seluruh potensi secara optimal mulai dari tenaga kependidikan, peserta didik, proses pembelajaran, sarana pendidikan, keuangan dan termasuk hubungannya dengan masyarakat. Pada kesempatan ini, lembaga pendidikan Islam harus mampu merubah paradigma baru pendidikan yang berorientasi pada mutu semua aktifitas yang berinteraksi didalamnya, seluruhnya mengarah pencapaian pada mutu.

Lulusan bermutu marupakan SDM yang kita harapkan bersumber dari sekolah atau madrasah yang bermutu (efektif). Sudah siapkah sistem pendidikan kita untuk menetaskan mutu SDM yang mampu berkompetisi secara profesional dengan bangsa lain

Selain itu untuk menjawab berbagai permasalahan yang ada di lingkungan pendidikan khususnya pendidikan Islam terletak pada Manajemen Mutu Terpadu yang akan memberi solusi para professional pendidikan untuk menjawab tantangan masa kini dan masa depan. Karena Manajemen Mutu Terpadu dapat digunakan untuk membangun aliansi antara pendidikan, bisnis dan pemerintah.

Abad ke-21 merupakan momentum yang penuh tantangan bagi negara sedang berkembang seperti Indonesia. Kita perlu mencari model baru manajemen pendidikan untuk meningkatkan mutu lulusan sekolah/madrasah. Tak ada salahnya jika mempelajari usaha-usaha di bidang pendidikan dalam beberapa dekade terakhir abad XX di negara maju, seperti Amerika, Jepang, dan Inggris. Negera-negera tersebut ketika itu merasa perlu menerapkan TQM (Total Quality Manajemen) atau Manajemen Mutu Terpadu dalam bidang pendidikan, tapi sekaligus sebagai model yang mengutamakan perbaikan berkelanjutan.

Manajemen Mutu Terpadu (Total Quality Management) dalam konteks pendidikan merupakan sebuah filosofi metodologi tentang perbaikan secara terus menerus, yang dapat memberikan seperangkat alat praktis kepada setiap institusi pendidikan dalam memenuhi kebutuhan, 
keinginan,, dan harapan pelanggan, saat ini maupun masa yang akan datang.[20] TQM merupakan suatu sistem manajemen yang mengangkat kualitas sebagai strategi usaha yang berorientasi pada kepuasan pelanggan dengan melibatkan seluruh anggota organisasi. Total Quality Management merupakan suatu pendekatan dalam menjalankan usaha yang mencoba untuk memaksimalkan daya saing organisasi melalui perbaikan terus menerus atas produk, jasa, manusia, tenaga kerja, proses, dan lingkungan.

Lembaga pendidikan adalah wahana proses belajar mengajar bagi peserta didik. Untuk meningkatkan mutu pembelajaran, banyak sekolah yang sudah menerapkan Total Quality Manajement (TQM) sehingga berhasil pada beberapa dekade terdahulu.

Dewasa ini perkembangan pemikiran manajemen sekolah atau madrasah mengarah pada sistem manajemen yang disebut TQM (Total Quality Management) atau Manajemen Mutu Terpadu. Pada prinsipnya sistem manajemen ini adalah pengawasan menyeluruh dari seluruh anggota organisasi (warga madrasah) terhadap kegiatan madrasah. Penerapan Manajemen Mutu Terpadu berarti semua warga madrasah bertanggung jawab atas kualitas pendidikan.

Sebelum hal itu tercapai, maka semua pihak yang terlibat dalam proses akademis, mulai dari komite madrasah, kepala madrasah, kepala tata usaha, guru, siswa sampai dengan karyawan harus benar - benar mengerti hakekat dan tujuan pendidikan ini. Dengan kata lain, setiap individu yang terlibat harus memahami apa tujuan penyelenggaraan pendidikan. Tanpa pemahaman yang menyeluruh dari individu yang terlibat, tidak mungkin akan diterapkan Manajemen Mutu Terpadu.

Dalam ajaran Manajemen Mutu Terpadu, lembaga pendidikan (madrasah) harus menempatkan siswa sebagai "klien" atau dalam istilah perusahaan sebagai " stakeholders" yang terbesar, maka suara siswa harus disertakan dalam setiap pengambilan keputusan strategis langkah organisasi madrasah. Tanpa suasana yang demokratis manajemen tidak mampu menerapkan Manajemen Mutu Terpadu, yang terjadi adalah kualitas pendidikan didominasi oleh pihak - pihak tertentu yang seringkali memiliki kepentingan yang bersimpangan dengan hakekat pendidikan.

Komponen-komponen dari model implementasi Total Quality Management dalam pendidikan adalah sebagai berikut:

- Kepemimpinan

- Pendekatan fokus terhadap pelanggan

- Iklim organisasi

- Tim pemecahan masalah

- Tersedia data yang bermakna

- Metode ilmiah dan alat-alat

- Pendidikan dan latihan
Pemimpin lembaga pendidikan Islam, khususnya di lingkungan pesantren dan madrasah merupakan motivator, event Organizer, bahkan penentu arah kebijakan sekolah dan madrasah yang akan menentukan bagaimana tujuan-tujuan pendidikan pada umumnya direalisasikan. Untuk mewujutkan hal tersebut maka kepala sekolah yang efektif adalah kepala sekolah yang memenuhi kriteria sebagai berikut:

- Mampu memberdayakan guru-guru untuk melaksanakan proses pembelajaran dengan baik, lancar dan pruduktif

- Dapat menyelesaikan tugas dan pekerjaan sesuai dengan waktu yang telah ditetapkan

- Mampu menjalin hubungan yang harmonis dengan masyarakat sehingga dapat melibatkan mereka secara aktif dalam rangka mewujutkan tujuan sekolah dan pendidikan

- Berhasil menerapkan prinsip kepemimpinan yang sesuai dengan tingkat kedewasaan guru dan pengawai lain di sekolah

- Bekerja dengan Tim manajemen.

- Berhasil mewujutkan tujuan sekolah secara produktif sesuai dengan ketentuan yang telah ditentukan.

Pada hakekatnya tujuan institusi pendidikan adalah untuk menciptakan dan mempertahankan kepuasan para pelanggan dan dalam TQM kepuasan pelanggan ditentukan oleh stakeholder lembaga pendidikan tersebut. Oleh karena hanya dengan memahami proses dan kepuasan pelanggan maka organisasi dapat menyadari dan menghargai kualitas. Semua usaha/ manajemen dalam TQM harus diarahkan pada suatu tujuan utama, yaitu kepuasan pelanggan, apa yang dilakukan manajemen tidak ada gunanya bila tidak melahirkan kepuasan pelanggan.

Keberhasilan aplikasi Manajemen Mutu Terpadu di sekolah diukur dari tingkat kepuasan pelanggan baik internal maupun eksternal. Sekolah dikatakan berhasil jika mampu memberikan layanan sesuai harapan pelanggan. Dengan kata lain, keberhasilan sekolah atau madrasah dikemukakan dalam panduan manajemen sekolah sebagai berikut:

- Siswa puas dengan layanan sekolah

- Orang tua siswa puas dengan layanan terhadap anaknya

- $\quad$ Pihak pemakai atau penerima lulusan puas karena menerima lulusan dengan kualitas tinggi dan sesuai harapan

- Guru dan karyawan puas dengan layanan sekolah.

Pada hakekatnya tujuan institusi pendidikan adalah untuk menciptakan dan mempertahankan kepuasan para pelanggan dan dalam TQM kepuasan pelanggan ditentukan oleh stakeholder 
lembaga pendidikan tersebut. Oleh karena hanya dengan memahmi proses dan kepuasan pelanggan maka organisasi dapat menyadari dan menghargai kualitas. Semua usaha / manajemen dalam TQM harus diarahkan pada suatu tujuan utama, yaitu kepuasan pelanggan, apa yang dilakukan manajemen tidak ada gunanya bila tidak melahirkan kepuasan pelanggan. Untuk dapat mencapai peningkatan mutu pendidikan sebagaimana yang diharapkan

\section{E. Kesimpulan dan Saran}

Jadi dapat disimpulkan bahwa kualitas mutu pendidikan dengan berbagai jalur, jenjang, dan bentuk yang ada seperti pada jalur pendidikan formal, non formal, Informal, kesemuanya itu perlu pengelolaan atau manajemen yang sebaik-baiknya, sebab jika tidak dikelola dengan baik tentu akan sejalan dengan kualitas mutu pendidikan yang tidak baik pula. Persespi masyarakat akan gambaran negatif tentang pendidikan yang ada akan tetap melekat dan sulit dihilangkan bahkan mungkin Pendidikan Islam yang hak itu akan hancur oleh kebathilan yang dikelola dan tersusun rapi yang berada di sekelilingnya, sebagaimana dikemukakan Ali bin Abi Thalib :'kebenaran yang tidak terorganisir dengan rapi akan dihancurkan oleh kebathilan yang tersusun rapi”.

Manajemen sumber daya manusia yang dikelola dengan menerapkan nilai islam di dalamnya pasti akan melahirkan sumber daya yang berakhlakul kharimah (akhlak baik/terpuji) semua manusia harus memiiki sifat akhlakkul karimah yaitu sikap yang baik sesuai ajaran agama islam yang nantinya akan terus berkembang di setiap lembaga-lembaga pendidikan guna untuk meningkatan mutu pendidikan.

Guru, Staf terkait dan setiap orang dalam institusi pendidikan turut memberikan jasa kepada para kolega mereka sesama pelanggan internal. Hubungan internal yang kurang baik akan menghalangi perkembangan sebuah institusi. Kualitas sumber daya yang baik tentu akan mendorong pertumbuhan mutu pendidikan yang baik pula

\section{DAFTAR PUSTAKA}

H. tahir wahid. abd., 2017, Pengembangan manajemen sumber daya manusia terhadap peningkatan mutu pendidikan, Vol. VI, Nomor 1, januari-juni 2017

Ahmad, Dzaujak, Penunjuk Peningkatan Mutu pendidikan di sekolah Dasar, Jakarta: Depdikbud 1999

Departemen Agama, Al-Quran dan Terjemahnya, Semarang: Toha Putra. 2001.

Hafidudin, Didin, dan Hendri Tanjung, Manajemen Syariah dalam Prakatik, Gema Insani, Jakarta, 2003.
Hamalik, Oemar, Evaluasi Kurikulum, Bandung: Remaja Rosda Karya,1990.

Mulyasa, E., Kurikulum Berbasis Kompetensi, Konsep, Karakteristik, dan Implementasi, Bandung: PT. Remaja Rosdakarya. 2002.

Nasution, M.N., Manajemen Mutu Terpadu, Jakarta: Ghalia Indonesia. 2004.

Prawirosentono, Suryadi. Filosofi Baru Tentang Manajemen Mutu Terpadu, Jakarta, PT.Bumi Aksara. 2002.

Qomar, Mujamil, Epistimologi Pendidikan Islam dari Metode Rasional hingga Metode Kritik, Jakarta: Erlangga, 2005.

Ramayulis, Ilmu Pendidikan Islam, Jakarta: Kalam Mulia. 2008.

Rosyada, Dede, Paradigma Pendidikan Demokatis, Jakarta: Kencana 2004.

Sallis, Edward, Total Quality Management, terj., Ahmad Ali Riyadi, Yogyakarta: Ircisod. 2006.

Sulistyorini, Manajemen Pendidikan Islam; Konsep, Strategi dan Aplikasi, Yogyakarta: TERAS. 2009.

Syafaruddin dan Irwan Nasution, Manajemen Pembelajaran, Jakarta: Quantum Teaching. 2005.

Syafaruddin, Manajemen Lembaga Pendidikan Islam, Jakarta: Ciputat Press. 2005.

Terry, George R., dan Leslie W. Rue, Dasar-Dasar Manajemen, terj. G.A Ticoalu. Cet. Ketujuh, Jakarta: Bumi Aksara. 2000..

Syafaruddin, Manajemen Mutu Terpadu dalam Pendidikan, (Jakarta: Grasindo 2002), hal.19.

Dede Rosyada, Paradigma Pendidikan Demokatis, (Jakarta: Kencana 2004), hal. 37.

Suryadi Prawirosentono, Filosofi Baru Tentang Manajemen Mutu Terpadu, (Jakarta, PT.Bumi Aksara. 2002), hal. 12.

MN Nasution, Manajemen Mutu Terpadu, (Jakarta: Ghalia Indonesia. 2000), hal. 28.

George R. Terry dan Leslie W. Rue, Dasar-Dasar Manajemen, terj. G.A Ticoalu. Cet. Ketujuh, (Jakarta: Bumi Aksara. 2000), hal. 1.

Sulistyorini, Manajemen Pendidikan Islam; Konsep, Strategi dan Aplikasi, (Yogyakarta: TERAS. 2009), hal. 13

Sunber Internet:

https://tujuhkoto.wordpress.com/2010/06/21/manaj emen-peningkatan-mutu-pendidikan-islam/ diakses 6 mei 2019

https://educational4net.blogspot.com/2010/06/mana jemen-peningkatan-mutu-pendidikan.html. diakses 6 mei 2019 